\title{
'Only the People can defend this struggle': The Politics of the Everyday, Extrajudicial Executions and Civil Society in Mathare, Kenya
}

\section{Introduction}

A pistol shot rings out in Mathare, an informal settlement in Nairobi, in the early hours of a chilly winter night. A mother, upon hearing the shot whose report rumbles through the still air, puts on her slippers and walks out to investigate as she is concerned that her teenage son is out late. She goes hurriedly to where the noise came from, and sees two policemen about to shoot a young man dead at point-blank range. After remonstrating with, she hears one of the policemen angrily say to the other: 'Damn it! Because of her interference we will have to let him go!', which they reluctantly do. Merely another unremarkable violent incident in the slums east of Nairobi, except for the woman's brave intervention that has allowed one lucky young man to secure reprieve from police violence, at least for now. ${ }^{1}$

Hardly a week goes by without media reports of police shooting dead young men: one week three 'thugs' are shot dead in daylight by police outside one of the author's regular coffee shops (Daily Nation 27 August 2014), another week five 'thieves' are killed at the entrance to an upmarket estate in West Nairobi ${ }^{2}$; and another along one of the city's main highways. ${ }^{3}$ And so it continues. Apparently, the narrative of 'thugs', 'thieves', 'criminals' and 'gang members', alone is sufficient to explain why these young men are treated in either such a cruel and degrading manner, and, ultimately, 'hunted' and even 'finished' by the police. To a large extent, a divisive public sentiment exists. For instance, a quick scan of the comments section on the Facebook page of the Nairobi News after the killing of 17-year-old Stephen Gichuru in Mathare by police on May 17, 2015, shows strongly worded opinions for and against such violence. It is worth, though, highlighting comments such as the one below by 'Biggy', which demonstrates the permeation of the 'live by the gun and die by the gun' condemnatory rhetoric:

Most of these youths do not want decent honest careers even when they are offered all opportunities. They prefer the quick money they get through violent 
crimes. Let them be gunned down by police bullets if that is the only language that they understand.

Beyond this rather common sentiment, when the extrajudicial executions happen outside of the 'slums' - like in those incidents listed above - the killings attract some degree of media attention, laying publicly bare the state's shoot-to-kill policy. But, otherwise, like the earlier anecdote in the slums, such incidents usually go unreported (Stephen Gichuru is one of the rare exceptions). Usually there the nation's media is not present to bear witness to the aftermath of shootings, which often involve unarmed young men. Witnesses claim Bonokos -a popular term for weapons planted by the police after the shootings- are often placed on the bodies of young men whose corpses were still warm. The reality, therefore, is the continuous violence enacted upon young men within the supposedly 'other' Nairobi: its slums. Why, then, do these events seemingly occur with such frequency, and yet civil society does nt appear to offer radical ways of tackling such violence. Or, put simply, following Pithouse (2015) who indeed 'counts and who doesn't' in the violent postcolonial city, and why?

The article looks at such experiences of 'everyday violence' in Mathare, ${ }^{4}$ and the challenges civil society face in addressing the extrajudicial executions (EJE) of young men. Above all, the paper seeks to better understand the apparent lack of any lasting solutions to the problem and also why EJE appears to be a 'normalised' phenomenon in Kenya. More specifically, since 2010, despite a purportedly transformational constitution and multi-sector engagement in police and policy reform, the problem of violence remains unabated, and as data shows, is worsening. Our analysis, therefore, locates EJE, along with community-level demands for safety, within the broader terrain of state and population interaction and political engagement (Chatterjee, 2004), as illustrated through two important dynamics. First, we recognise the important role and different contributions of a wide variety of non-governmental organisations (NGOs) in addressing the deep-rooted problem of police violence. But in explaining the limited impact of their responses we identify how 'NGOisation' has dented their impact. Second, conversely, we highlight the grassroots struggles of activists in Mathare, often in response to NGO interventions. We use participant observation of activities associated with the Mathare Social Justice Centre (MSJC); these include field mobilisation events, 
and community 'dialogues' that seek to document and raise awareness of the scope and nature of EJE, and qualitative interviews with 8 activists. Our methodology and analysis strives to incorporate the potential for 'autonomous social forces' (Hearn, 2007) to act.

In our reading of EJE, it is the politics of the everyday that shape understandings of political engagement. It is this 'everyday violence' we seek to use to explain the seeming disjuncture that exists between grassroots and particularly NGO efforts against EJE.

\section{Theorizing The Politics of the Everyday: Engagement and Violence}

Pithouse's (2015) provocative piece describes how the spatial order of the colonial city continues to structure interactions between the state and those governed - to the extent, he argues, that we normalise the occurrence of police killings. Other authors support this claim, such as Ndlovu-Gatsheni (2011:7), who argues that it is the 'coloniality of being' that connects the colonial period to the present: the horror of colonial violence enacted upon racialized subjects that becomes 'routinised as the African mode of being'. These are important elements in seeking to explaining the apparent fissure in political responses to violence within the postcolonial city. Chatterjee (2004), however, deepens our understandings of the dissonance between these excluded spaces where inhabitants 'are only tenuously, and even then ambiguously and contextually rights-bearing citizens in the sense imagined by the constitution' and 'an actually existing arena of institutions and practices inhabited by a relatively small section of the people' (Chatterjee 2004:38). Though it's debatable whether Chatterjee underplays the potential for the state extending rights to the excluded, the major contribution of his conceptual frameworkand of particular relevance here - is to identify a split in the political field: on the one hand, civil society, as 'the closed association of modern elite groups, sequestered from the wider popular life of communities, walled up with enclaves of civic freedom and rational law'; and on the other political society, which he defines as 'large sections of rural and urban poor, [who] make claims on government not within the framework of stable constitutionally defined right and laws but direct political negotiations...' (Chatterjee 2004:4). What enables this political negotiation by the excluded is the shift in state organisation towards governmentality and its attendant activities and expectations, thus producing a new interface between government and the population, according to Chatterjee. But his is not a disabling and depoliticising governmentality but 
rather one that enables political encounters and negotiations. Chatterjee's analysis is also politically dynamic as it centres upon the everyday struggles of the excluded to survive and eke benefits from state interventions and programmes. In so doing, Chatterjee forcefully moves beyond some previous analyses that tend to regard the grassroots as somehow "pre-modern" and in need of taming and civilising by 'civil society'.

But his framework (even allowing for modifications over the years), has opened up several lines of critique (see Gudavarthy, 2014; Hart, 2015). Most problematically, Chatterjee over-states the binary separation of civil and political societies (as if 'oil and water' following Corbridge's assessment in Gudavarthy, 2014), and underplays their inter-connectivity in terms, for example, of how modern elites routinely break laws to their own advantage. Conversely, many excluded communities strive for legal protection even as they deal in illegal activities. Similarly, many voluntary associations that comprise political society in fact have to mirror the regulatory structures of NGOs within civil society, such as registration and the official organizational hierarchies to achieve a particular status. Rather, what may be taking place is the use of different types of political engagement rather than any real empirical difference between them (see individual chapters in Gudavarthy, 2014). Furthermore, Chatterjee's lens of governmentality - this is arguably less relevant in Nairobi's neglected slums devoid of the most basic of government programmes - is criticized for lacking a transformative potential because of his focus on incremental micro-politics. It can also be argued that the lack of radical potential is also underemphasized because Chatterjee does not look at broader social movements that contest state sovereignty. Chatterjee, however, maintains that he is simply not seeing that kind of politics in his fieldwork.

These criticisms, and indeed Chatterjee's erudite responses to them $(2011,2014)$, not withstanding, his analysis remains of central significance precisely because of the persistent zones of exclusion, like those in which young men in Mathare find themselves. Certainly, these spaces are and can be breached. But what if that is the exception rather than, as we see it, the norm of exclusion? We recognise Chatterjee's continuing relevance for what we are seeing in Nairobi. However, we also believe that his version of governmentality unfortunately tends to obscure the violence and brutality that is the 
dark underside not only of governmentality, but also of how that violence embeds itself in the the politics of the 'everyday'.

By extending these claims it becomes clear that an integral feature of the urban postcolonial condition is the experience of different forms of violence - a condition that has clear implications for Kenya's development more broadly, and more specifically the ability of young men from impoverished conditions to survive and thrive. In addition to Pithouse's and Ndlovu-Gatsheni's assertions, and with reference to Chatterjee, this paper deploys Das' (2007) work on the 'descent into the ordinary' as the primary conceptual tool to understand the logic of everyday police violence and people's responses to it. We argue that the way grassroots activists articulate their lived experiences of extrajudicial killings - from dealing with the loss of family members, neighbours and friends, to the real and perceived dangers of walking through certain parts of Mathare - is 'a mutual absorption of the violent and the ordinary' (Das 2007: 7). It is through these processes to define and defeat such acts of extreme violence and their associated trauma, that activists create their own theory of violence: one that frames their strategies and intentions particularly vis-à-vis NGOs and more importantly sheds light on why and how they themselves have mobilised. The emphasis on the 'ordinary', 'everyday' or 'normal', as inspired by Das' work, is highly important to this discussion as it feeds into the debate described in greater detail below, regarding whether NGOs can actually capture the essence of what local people - in this case in Mathare - experience and subsequently mobilise in productive and meaningful ways.

Focusing primarily on the women who suffered abduction, rape, and the murder of husbands, brothers and sons during the Indian Partition (1947) and anti-Sikh massacres (1984), Das argues that her interlocutors define themselves as 'subjects' in unexpected ways. More specifically, rather than creating an 'opposition between the experience of violence as a victim/survivor and that of the subject ... [it is] the ability to recraft the symbols and genres of mourning that made them active in the highly contested domain of politics' (217). We extend her incisive analysis to the context of EJE in Mathare: it is the very narrativisation of everyday experiences that enables the grassroots movement studied to separate itself and articulate a difference from the NGO work currently taking place, as will be discussed in the later sections. They can identify as victims but this 
positioning has multiple 'plot-lines' and repertoires that do not indicate a

submissiveness or defeat. On the contrary, for these activists it is precisely 'victims' who simultaneously hold agency in halting the everyday violence that frames their lives, a

violence that they know most acutely as it has become mundane. Therefore, like the women Das (2007) speaks of, this understanding (or theory) of violence as part of everyday life allows activists to self-identify beyond the framing purely of 'victims' and instead recognise themselves as people best positioned to encroach and halt this violence in its everyday manifestations. Thus, for Mathare social justice activists the violence is linked to the 'normal' or 'everyday' - through comments about the frequency of such deaths, the sense that it is a 'normal' way to die, but also that it must be a normal and everyday fight to halt its fight, and preserve life in their community.

What makes this study timely and of deep empirical and theoretical interest - in addition to the deep 'ethics of responsibility' (ibid: 218) that we as researchers feel when documenting violence - is the youth-led aspect of this work and their focus on the 'everyday'. The 'shared symbols' through which activism becomes materialised is intertwined with youth and local marginalisation from NGO spaces (due to age, experience, language and other barriers), the commonality of experience that often becomes lost in translation through regimented and bureaucratic ways of operating at NGOs, and the very real risks that activists take on that NGO staff often do not bear.

We thus seek to link this very anthropological and geographical understanding of social worlds and lived experiences to development studies and understandings of civil society: namely, how do NGOs fit into this 'normalised violence' and at what points are divergent (anti)politics between civil society and political society (Chatterjee, 2004) created at the grassroots level?

\section{Extrajudicial Executions in Kenya}

While there has been literature on police violence in informal settlements, particularly in the Latin American and South Asian context (see Auyero, 2012 and Mehta, 2004), the Kenya-based literature is largely focused on the 2007 and 2013 elections and furthermore, the intersection of everyday violence and justice efforts is particularly understudied. 
EJE, torture and cruel and degrading treatment at the hands of the police have been ever-present stains on Kenya's human rights record. Prior to and following

independence in 1963, there have been gross human rights violations associated with each administration. From the post-1991 era, though civil-society organisations (CSOs) started using the newly available opportunities to engage in democratic spaces, police reform has still lagged. It is equally important to note that despite the new arena for engagement, some five years prior to the enactment of the constitution, Holmquist's (2005:213) pertinent observations about the 'gap' between the national level and popular demands.

The 'gap' resonates with the approach by Chatterjee (2004), mentioned earlier, which suggests caution when immediately celebrating the declaration in 2010 of a new

Constitution, that included a Bill of Rights with articles on protection from torture, and cruel, inhumane or degrading treatment or punishment. Though clearly very important features of the new dispensation, these provisions have not proven sufficient in prohibiting torture and providing redress clauses. One of the key drivers of torture, for example, is the strong correlation in Kenya between the power to arbitrarily arrest and unlawfully detain an individual. Criticisms include the 'persistent allegations of on-going EJE, enforced disappearances, and excessive use of force by police officers, especially during 'special operations', as well as the low rate of investigations, and prosecutions of such acts' (see UNCAT, 2013). Furthermore, there has also been a paradigm shift away from political victims of torture to one of 'everyday' abuses associated with the criminalisation of poverty and police excessive use of firearms. These drivers all suggest that substantive protection and promotion of human rights requires a legal, policy and institutional framework (KHRC, 2013) and, we should add, grassroots mobilisation of civil society. Many CSOs have pro-actively sought to reposition and renew their relevance for an era laden with possibilities for reform. However, in transitional states such as Kenya, a salient reminder is that:' $[t]$ he cohabitation between politicians and civil society organisations, particularly those in the human rights and democracy sector, becomes a delicate balance' (Miano, 2009: 226). 
It is a balance currently being tested by two inter-related challenges: state responses and public reaction to waves of insecurity and violations by the state plaguing the country (Open Society, 2013); and also the politics surrounding the International

Criminal Court (ICC) cases, which have also engulfed state-civil society relations. Though there are new possibilities for engagement, Kenyan civil society activists are very concerned about state-led attacks on CSOs that induce unpredictability in the policy and political environment (Kiai, 2013). Another enduring challenge is therefore the level of impunity following abuses that have been 'normalised and institutionalised' in Kenya (TJRC, 2013). In relation, a vital ingredient in police reforms concerns whether an adequate balance between internal and external stimuli can be created to support incentives for substantive change. Evidence suggests that it is the top echelon of police services that needs to embrace reforms and then convey them to the rank-and-file police culture. But in Kenya it is precisely 'the top' that understand the police force as a means to exert political control and maintain vested interests (Hornsby, 2013).

The police are considered to be the most corrupt and least trusted public institution in the country (see Hornsby 2013). Since 2002, with a genuine multi-party transition, NGO and police activity has taken place, as mentioned, within a landscape of political and policy reform. Yet, the need for broader systemic reform soon became apparent as the Kibaki administration began to utilise older modes of state repression - as seen under Moi's authoritarian government - most notably, with the renewal of EJE. One organisation tracked 1,873 deaths resulting from gunshot wounds over a five-year period, $87 \%$ of which occurred in Nairobi (IMLU, 2014). While the majority of these deaths (67\%) occurred during law enforcement interventions, it was often unclear the circumstances of police involvement, particularly why the use of deadly force became necessary. While we would argue that this is a very conservative tally, even this low-ball figure amounts to effectively one police death every day for five years - a situation that is unfortunately considered 'normal' by mainstream media and the many members of the public. Another organisation, the Oscar Foundation Free Legal Clinic, released a report in 2008 that documented at least 8,000 young men had been killed by the police in what was, ostensibly, a crackdown on the Mungiki movement. ${ }^{5} \mathrm{~A}$ year after that report was released, human rights lawyer Oscar Kingara and his collaborative researcher John Paul Oulu were assassinated, ironically in a similar fashion to the very 
extra-judicial killings they sought tirelessly to document. The Oscar Foundation Free Legal Clinic was the only formal organisation that came close to documenting what was being lived on the ground (for instance, one of the authors worked with young women in one ward in Mathare constituency between 2007-9, and many of these women had husbands and brothers, even a sister, who had been disappeared. Some of these families are still haunted by the fact that they never found the bodies of their kin to bury).

While not to the same extent as the 'Mungiki period' (i.e. the period of EJE and disappearance of militia members, particularly, 2006-2007), young people, especially young men, are still being shot at an alarming rate in Mathare and other poor urban settlements. An extrajudicial working document compiled by Mathare Social Justice Centre, itself a complex and arduous task due to the trauma, silence and fear that circulate around these killings, shows that most of the young people shot are under age 30 and have been framed by the police post-killing as 'thieves' or 'threats to security'. ${ }^{6}$ Furthermore, their families tend not to register a case with NGOs, or, the police or police oversight committees for a variety of structural factors including lack of bus fare, fear and overall distrust of these bodies. For those who do register a case, it is a story of being engulfed in the bureaucratic 'politics of waiting' (Auyero 2012) (referred to in police-speak as 'further investigations') that is exacerbated by widely held ideas of young men in Mathare as criminals deserving of death.

\section{NGOs and Democratic Space: Professionalisation to What Effect?}

A well-developed literature has emerged on NGOs, looking not only at their

contributions but also a critical examination of their practices and structures (see Lewis and Kanji, 2009; Hearn, 1998, 2001; Mercer, 2002 amongst others). In recent years, debates have begun to identify, more explicitly, the specific ways in which many NGOs are not only complicit in furthering neo-liberal modes of contesting the state but also in acting at the expense sometimes of those they claim to be supporting. The emphasis on donor driven accountability also contributes to de-politicising NGO work and to further reflect the regulation and containment of grassroots and other community-based struggles. Managers are pressured to 'professionalise' (O'Flahtery and Ulrich, 2010), and act, seemingly, with middle class interests. There are additional aspects to the process of professionalisation, including, for example, how NGOs become side-tracked by having to 
fulfil contractual obligations to strengthen and perform technical and managerial capability. Our aim here is not to rehash these debates but to rather explore whether NGOs, specifically in Mathare, meaningfully capture what local people experience and subsequently mobilise in inclusive and productive ways.

In Kenya, for example, NGOs frame EJE as part of the current sinister 'counter-terrorism' regime to attract money from larger human rights bodies such as Amnesty International. This narrow perspective does not view EJE as part of the very longue duree of colonial and neo-colonial urban governance that legitimises these kinds of violence(s). Moreover, the spatial dimension of EJE - as specific 'killing spots' in slums and the heightened occurrence in the wider Mathare locale itself - is disregarded.

The following section looks at responses of contemporary grassroots human rights activists in Mathare, as well as residents' concerns regarding issues of EJE.

\section{Grassroots Engagement}

Youth have been a longstanding part of daily life in Mathare. Due to a climate of the very legitimate fear that surrounds mobilisation, it is only in the last few years that they have been more explicit about and comprehensively organising around these killings. We draw on interviews from eight respondents who form most of the core members (and creators) of the Mathare Social Justice Centre (MSJC). Our main discussion with these youth activists living in the Mathare constituency focused on the creation of MSJC: the focus from the onset on EJEs and why the activists felt it was necessary to come together despite the number of NGOs working on EJE issues. We also draw on our observations from four public fora held by MSJC, where local community members aired grievances and suggested ways forward; the first three events attracted over 80 participants at each. These fora have been important public events to situate a response to EJE in the 'everyday', as residents make efforts to link violence to the social fabric, in a vein similar to the work by Das (2004) mentioned earlier.

One respondent, when asked about why she had joined the MSJC, and chose a leadership position, identified a deeply embedded context of police brutality. She drew on her own terrifying encounters with the police and, more traumatic, the killing of her brother by 
the police. Common to the accounts of the activists we interviewed, she also talked about the current and on-going police actions in her settlement:

I want to see the police behave. I want police to give us peace and respect us as citizens of Kenya. Police are very notorious. I was with dad and I had left my phone. I went to the house to get it...there was darkness and no electricity for last three days in the settlement. As I went back I heard gunshots and I was told by my dad to get into the house but I peek...I can see three policemen...they have cuffs and they are beating people seriously, and then shooting into the air...I go out and watch...a person being beaten is shouting saying they are not doing anything wrong and the police are saying "shut up"- I want this to stop! I feel the police are not competent...and it's the same one misbehaving several times... (R6).

Her references to electricity outages, gunshots, police brutality, and vulnerable shack dwellings, all invoke insecure spaces. Indeed, one MSJC-organised forum, though intended to explicitly explore EJE, saw participants share such experiences linked to broader structural issues, such as the pattern of land-grabbing and, in addition, the climate of fear that pervades Mathare:

At the meeting we shared experiences with land-grabbing and extrajudicial killings, and the connections between these that occur due to the collaborations between landowners, the chief, the city council and the police who threaten many youth including our members... While we spoke and shared with each other, one issue that was constantly raised was the issue of fear. People feared that if they said anything 'tomorrow it would be them' and so many of them were guarded and refrained from talking for fear of informers. This makes us wonder whether Article 26 of the constitution which gives us the right to life means anything. ${ }^{7}$

Everyday concerns are therefore invoked alongside rights enshrined in the Kenyan Constitution. But action is inhibited by fear; it is this 'tomorrow' and the fear of not living to see it that deepens what the everyday means for residents. MSJC members regard the difference between themselves and other actors in the community as how they were less afraid of tackling issues compared to others. Many of the group members often voiced how they are were 'tired of losing generations' and did not want to see that happen anymore. Another respondent (R7), for example, had been a former gang member. After seeing his entire 'squad' of 15 members killed either by the police or rival gangs, and the 
shock of being the only survivor, this respondent was compelled to challenge the gang's fatalism and the apparent expendability of young men in the slum and so he joined MSJC.

Another theme, or 'shared symbol' to draw on our earlier discussion of Das (2004) has been the activists' rejection of the pervasive labelling of young men as 'thieves'; MSJC members and audiences have instead inverted this discourse, labelling police and political leaders as the real 'thieves' and 'criminals' of the country. Similarly, another narrativisation tactic is to evoke concerns of childbirth and parenting, but in the specific context of the everyday inevitability of the police killing their children because '[T] he sentiment from many people was "why should we give birth when the police are killing ourchildren with such impunity?"'...(ibid.).

Themes therefore emerged that lay the foundations for a divergence between residents and their everyday, and those actors supposedly representing them. One particularly important set of actors are NGOs. And in specific discussions with activists, several additional themes emerged from interviews.

\section{The Grassroots and NGOs}

The activists depicted a metaphoric gap, along the lines of that mentioned by Chatterjee earlier, between themselves - as grassroots - and the NGOs. For instance, one respondent described NGOs in the following terms: 'They only recognise the people "up there", whereas we feel we are not being supported as we are "down here" [literally in a valley]. And the NGOs act as cartels ${ }^{8}$ for their own self-interests; work with bigger people and do not address our issues.' The same respondent also explained this 'gap' in terms of the lack of appropriate actors to whom she could turn to and provide the extensive data on violence -including gun shots- she collected on a monthly basis because the 'bigger' actors did not demonstrate any interest.

In relation, a particular affront to local activists was the perceived lack of presence on the ground of NGOs purportedly working on EJE. One high profile event was evoked by respondents who attended $(\mathrm{R} 2,3,8)$. It concerned a 'field day' by the Kenyan National Human Rights Commission (KNHRC) to document cases, at an event held at the Huruma Sports grounds prior to the election in 2013. But activists strongly criticised the event as 
a sham because they argued that there were inadequate attempts to work with local activists in advance, which was also reflected in poor numbers attending. One spoke about KNHRC's fleeting presence, and how she observed that many of the tents erected for the day remained empty because the organisers had not effectively mobilised the community, again indicating tenuous links to the community.

In addition, another (R8), also accused the KNHRC of using a locally compiled report inaccurately and, indeed, as a result, grossly undercounting the prevalence of EJE in the settlement. What is interesting to note is how the activists' criticism of the event was articulated angrily by reference to differences in class, in terms of the status and also geographic isolation of the organisation (more accurately, a government commission) in question in its posh suburb of Nairobi. Indeed, these attributes were all regarded as indicting lack of relevance to the community:

The police and the Kenyan National Human Rights Commission [and others] came out to us for a field day. And we said: "Don'tyou come here in your suits and in your big cars ... because we are the ones who deal with the violations ... this is why we are proposing our own centre [MSJC]."(R3).

For local activists, such an event therefore epitomised the apparent gap between 'respectable' civil society and their insincerity in working with the local community. Additional contributory factors to the perceived 'gap' also concerned levels of education. Some activists suggested that lower education, also denoted by a lesser ability to speak 'good' English, formed a social barrier that inhibited activists from going engaging civil society. The grassroots then becomes reified as being 'on the ground' and maintaining the habitus and vernacular of the community themselves.

\section{Disproportionate Risksand Costs}

Almost all the respondents also highlighted the nature of a 'gap' in terms of resources and disproportionate risk, both of which often overlapped. For human rights activists and residents, making reports about incidents at the local level could prove a serious risk for themselves and their families. More specifically, if the confidentiality or the 
guarantee of protection could not be promised, then giving evidence against a violator meant risking becoming a victim:
A major challenge here in Mathare is witnessing cases- people always ask about their safety if they act as witnesses. People fear giving reports; and people also are not aware of witness protection and they don't feel it in any case. For example, I would choose not to if it meant... [that] I might be covered and protected but my children and family would not. (Respondent 2).

In relation, there is a sizeable cost burden in getting victims help, and this includes, for instance, transporting the victim to the hospital and potentially helping with recuperation costs. The paucity of resources was keenly felt especially in contrast to those of the big NGOs.

\section{ProfessionalismofNGOs/Civil Society}

Associated with the disconnect mentioned above, the respondents talked about a sense of exclusion from NGOs, where they felt disqualified because they did not possess 'proper' education credentials. It was a double-edged complaint: on the one hand respondents conveyed a sense of being overlooked, but also acknowledged that one could never qualify for a job given the insurmountable educational barriers. Both the social and geographic gaps coalesce in the activists' understanding of their position visà-vis NGOs: namely that 'NGOs don't employ people from the slums,' (R1) nor do they appear to listen to the voices from these spaces.

The critique activists made of NGOs having strict educational qualifications is also tempered by the rejection of what they depicted as a 'soul-less' pursuit of degrees, a careerism that seemed to take the energy out of the movement. One leading human rights defender puts it as follows: 'We had a movement in place, but after the donors came then it became about degrees and the professionalism has killed passion. And no new cadres with an understanding of human rights are emerging. The movement is no longer growing' (R1). 
The same activist also drew out some other less obvious implications of professionalisation, namely, in terms of what it meant for strategising and tactics for furthering human rights struggles:

I think [the National level NGO in question] directors and staff, they would not feel ok to take coffins of extra-judicial killings victims to parliament building or to the office of the Inspector general of police ... as a way of protest, as before ...which was our activism, our court appearance solidarity and, now, this kind of human rights activism is not for professional human rights workers who are looking for career in government human rights agencies, in boards of Directors, are magistrates and middle class working in the government.

But this is of course not to say that activists themselves are not looking for enhanced opportunities that NGOs also represent. Many could, for example, rattle off the number of workshops and trainings provided by NGOs that they had attended. Furthermore, activists all drew instrumentally upon seeking (limited) protection that some NGOs can offer, particularly to local human rights defenders. Some respondents had even been employed short term by NGOs and let go of for varying reasons. Though there are clearly overlapping interests, which sometimes coalesce, it does not dissipate the sense of exclusion from access to resources and influence that the NGOs command. Activists repeatedly scorned the waste of resources by NGOs -for instance, inappropriate training in expensive hotels or 'fake' local workshops- in contrast to their actual needs and struggles not being met. Indeed, knowing how much in the way of resources are directed to the professional human rights sector and that only a tiny amount trickles to local activists work in slums, and that they face various barriers, is likely another important reason for regarding NGOs as distant from the 'everyday'.

\section{Data 'mining'}

Alongside the emergence of professionalism, another inter-related effect concerning the shift to evidence based interventions is the role of information gathering and compilation, and the attendant use of research and reports. A widespread view existed of NGOs as too preoccupied with mining informal settlements for information without any feedback loop or process to follow-up the report writing. In other words, activists 
considered them as opportunistic 'parachute' researchers and consultants. This

attribution stemmed from a perception that NGOs needed to be seen as evidence based, as if engaged with the grassroots, and so heavily relied on 'producing' data from

informal settlements towards the ends of their funding cycle, bearing in mind that their

report writing periods needed to demonstrate an 'engagement' with the grassroots. This tendency, inevitably, according to the activists, resulted in a superficial presence.

Respondents recalled an event where another high profile NGO documenting EJE and

building forensic evidence for specific cases, invited local young men and members from the local police force to discuss crime and policing in Mathare. Throughout the

proceedings, local activists were concerned at how the meeting became an opportunity

for the police to profile young men and gather information that was then used against

them being passed on to the local police station to identify attendees who had perpetrated the crimes. The forum ended up generating conflict at community level, and the NGO in question did not return, nor did any subsequent follow up of the situation to mitigate this tension. As a consequence, the issue of information extraction was therefore associated both with the risk of sharing information and also the use and validity of the findings and misplaced sending priorities resources. As articulated by one respondent (R2):

Whereas an NGO is just an office, maybe [with] nice computers, but we are the ones with the information and it is risky for us...We feel donors don't realise the challenges we face- and so they don't get the real report. Big organisations don't

know me. We don't know how they will use information nor about the impact- so many people don't bother to approach them.

The use of reports was associated with spaces other than within which the information was gathered. Respondents described their own role in assisting in the report process, but then only for the final product to be presented in distant fora, not only in elite spaces of Nairobi but also in New York and London, which were simply inaccessible for the people whose violations were the basis of the reports. The perception of data and experiences extracted in order to feed an image designed for 'impact' on donors and the national media were considered as further proof of divorce from the grassroots

\section{Ethnicity}


Another barrier identified by activists involving NGOs included the role of ethnicity and how this politicised accountability. Most visibly, respondents made a link to the broader contemporary problem of the politicisation and active encouragement of ethnic

divisions by politicians in Mathare, and in the country at large. There had been several instances of the harassment of local human rights defenders, especially those who shone light on the corrupt actions of local politicians. Respondents described how the human rights movement was dealt a severe blow by alleged 'violators' being voted through their parties into national government. In relation, the ICC cases also encouraged an ethnicisation of human rights issues. Instances involved human rights defenders, from the President's ethnic group, who were allegedly rewarded either to act as spies for the ruling Jubilee coalition or inproviding deliberately false evidence at the ICC hearings.

But ethnicisation had already started and apparently escalated in the transition from Moi's KANU regime to the next administration led by Mwai Kibake. Respondents spoke about their perception of the ethnicisation of institutions and actors, and how several NGOs were perceived as predominantly representing the interests of one or other particular ethnic group. It has led to implications for whether or not cases are pursued. In dealing with sensitive information about perpetrators, for example, ethnic affiliation is not considered neutral but rather added in as a factor in the calculation of risk. All respondents mentioned that they would think twice about approaching particular NGOs because of their ethnic outlook, due to it being both pointless but also potentially dangerous. One (R3) mentioned, for example, how he had collected what he perceived as strong evidence on three policemen involved in EJE. But he feared the consequences of delivering the information. One prominent NGO was regarded as sitting on the information presented and failed to respond, a contention from the grassroots that is heard widely. At other times, the risk is that sensitive information may be passed on to the accused violator. For this activist, the distrust was related to how ethnicity confused the clear distinction between duty bearer and rights holders because the two can 'can become friends' due to shared group affiliation. Whether in law enforcement, or, otherwise, actors were described more generally as '...people, even in NGOs [that] are in ethnic cocoons more than ever...'. Another allegedly ethnicised NGO includes one prominent in the work on torture and EJE, where the respondent had been employed: '[T] he directors of [ the national level NGO] also became complicit with the NARC regime 
[political coalition that replaced Moi's KANU regime], as some of their relatives were working in government; they would sanction against extra-judicial killings or prison reports that would expose the regime.'

Another respondent (R2) spoke of attempts to pursue complaints against local police involved in fabricating robbery, allegedly for their own gains. But upon approaching the ombudsman who was from the same clan within the ethnic group as the accused were from, the respondent was asked to drop the case immediately. There are surely many other factors determining the strength of allegations, and therefore the grounds to pursue a case. Nonetheless, it appears that ethnicity is very important in determining whether an issue or case will be pursued.

\section{Discussion}

A fissure in perception and actions is very apparent. And though we don't want to give the impression of any absolute binary separation between 'civil' and 'political' society because activists clearly, as mentioned, at times overlap with civil society spaces and resources, there is, nonetheless, undeniably, an exclusionary logic taking place. But even when these harmful effects occur, does it necessarily imply that NGOs are inevitably always ignoring or compromising grass roots activism?

Neocosmos (2007) maintains that NGOs and human rights can never truly exist in a discrete space. He reasons that NGOs are institutionalised within states, and this renders them deeply ambiguous in relation to power. This and related critiques of the channelling of social change through institutional spaces prescribed and largely controlled by the state, go to the heart of debates over tactics and terrains of struggle in many African countries. As such they have special salience because many of the main preoccupations of rights-based NGOs in South Africa, and increasingly in Kenya, for example, has been to use institutional arenas, such as the policy and legal system to secure rights. In terms of political opportunity and engagement by NGOs, Madlingozi (2014) regards the importance of the scale at which an organisation works as having significant bearing on their tactics. In other words, there is a clear distinction existing between national and local levels. The national level organisations tend to be better resourced and through elite connections are able to successfully harness the generous 
civil and political spaces that exist in a country like South Africa. On the other hand, local counter-hegemonic organisations struggle to mobilise resources and encounter oppression and violations of their rights.

Arguably, more nuance might be provided to the debates by actual empirical assessments and reflections on whether democratic space has been opened or closed (Langford, 2015) by NGOs. Documenting actual outcomes and successful modalities such as alliances between local activists and professional actors- would ensure against essentialising NGOs. In so doing, the benefits of being located outside institutional spaces may be exaggerated and counterproductive to building robust democracies. There is also evidence of how subaltern communities have worked in alliance with these same professionals, for example, which may at times serve to sustain smaller organisations and movements (see Madlingozi, 2014). Nonetheless, the evidence presented here suggests that in Kenya the opening of democratic space and 'civil society' has still to find its way to excluded spaces like Mathare.

Thus, how NGOs might even become complicit in managing and structuring dissent in ways that do not challenge underlying power relations requires contextual empirical analysis. Though we risk down playing many of the practical challenges and difficulties that NGOs face in working with grass roots communities, by focusing upon activist perceptions we have identified several tangible reasons for their exclusion from 'civil society'. NGOs are currently defending their political space from government attacks in Kenya, and this also takes up time and resources. And there have been some successes, so this assessment is by no means intended to be black and white. Without therefore pointing fingers at NGOs as a whole, it is worth noting the structural deficiencies of civil society in terms of the context of deep class, political and ethnic divisions. Donors and others, therefore, should still address how funding contributes to the divides between popular interests and elites described in the article. Though interventions may be targeted at doing the 'right' thing, this should not divert attention from less obvious but perhaps unexpected outcomes and effects. Certainly, we detect a 'gap' with civil society at the grass roots level that under-develops concerted action. 
Notwithstanding this, we are not necessarily arguing for purely autonomous space, or, we believe, reification in any simple terms of 'grass roots' in binary opposition to 'civil society'.

\section{Conclusion}

How then are we representing this grassroots initiative and what theories of violence are youth activists utilising? It is apparent from the mobilisation efforts in Mathare that youth attempts to rearticulate EJEs and the violence surrounding them in a way that brings the 'everyday' into focus - given that this is something that the activists as youth, and many as male, have to encounter on a daily basis- is a necessary starting point for framing and developing action. Without romanticising their efforts, it can be argued that the activists' frustrations with NGO work, and indeed their marginalisation, become a powerful set of 'shared symbols' justifying their own efforts. Though action is

subsequently then also constrained or enabled by political opportunities and alliances -a subject for further research- the articulation of their frustrations forms the impetus and point of divergence at which the activists envision alternative ways of working from NGOs. It is principally to their own actions, however, that they turn to for justice, because as one activist (R1) shared: 'only the people can defend this struggle'.

\section{Bibliography}

Auyero, J. (2014), Patients of the State: The Politics of Waiting in Argentina, Durham: Duke University Press.

Chatterjee, P. (2004), The Politics of the Governed: Reflections on Popular Politics in Most of the World, New York: Columbia University Press.

Chatterjee, P. (2011), Lineages of Political Society: Studies in Postcolonial Democracy, New York: Columbia University Press.

Chatterjee, P. (2014), 'The Debate over Political Society', in A. Gudavarthy (ed.): Reframing Democracy.

Das, V. (2007), Life and Words: Violence and the Descent into Ordinary, Berkeley: University of California Press. 
Gudavarthy, A. (2014, ed.), Re-Framing Democracy and Agencyin India: Interrogating Political Society, London, New York, Delhi: Anthem Press.

Hart, G. (2015), 'Political Society and It's Discontents', Economic \& Political Weekly, l, 43, pp. $43-51$.

Hearn, J. (2001), 'The Uses and Abuses of Civil Society in Africa', ROAPE, 87, pp. 43-53.

Holmquist, F. (2005), 'Kenya’s Antipolitics', Current History, 104.

Hornsby, C. (2013), Kenya: A History Since Independence, London:Tauris.

IMLU (2014), 'Summary of Extra Judicial Executions by Police', January 2013- February 2014.

Kenyan Human Rights Commission (2013), IMLU's April 2013-March 2014 Narrative, Financial and Audit Report.

Kiai, M. (2013) 'In Kenya, averting a move to strangle civil society with the financial noose'.

https://www.opendemocracy.net/openglobalrights/maina-kiai/in-kenya-avertingmove-to-strangle-civil-society-with-financial-noose (accessed, November, 2013).

Lewis, D. and Kanji, N. (2009), Non-Governmental Organizations and Development, London: Routledge.

Madlingozi, T. (2014), 'Post-Apartheid Social Movements and Legal Mobilisation', in Langford et al (eds) Socio-Economic Rights in South Africa, Cambridge: Cambrdige University Press, pp. 92-130.

Mehta, S. (2004), Maximum City: Bombay Lost and Found, New York City: Alfred A. Knopf Publishers. 
Mercer, C. (2002), 'NGOs, civil society and democratization: a critical review of the literature', Progress in Development Studies, 2; 5.

Miano, J. (2009), 'Governance and Democracy in Kenya: Challenges for Human Rights', in Human Rights NGOs in East Africa (Fountain: Kampala).

Ndlovu-Gatsheni, S.J. (2011), 'The logics of violence in Africa',Working Paper No. 2, Ferguson Centre for African and Asian Studies, Open University.

Pithouse, R. (2015), 'They die there, it matters not where, nor how', Daily Maverick, 16 September.

O’Flaherty, M. and Ulrich, G. (2010), 'The Professionalization of Human Rights Field Work', Journal of Human Rights Practice Vol 2, Number 1, pp. 1 -27.

Open Society Initiative (2013), "We're Tired of Taking You to the Court": Human Rights Abuses by Kenya's Anti-Terrorism Police Unit.

The Truth Justice and Reconciliation Commission of Kenya (2013), Final Report. http://digitalcommons.law.seattleu.edu/tjrc/.

UNCAT (2013), Concluding observations on the second periodic report of Kenya, adopted by the Committee at its fiftieth session (5-31 May 2013).

\section{Additional methods}

8 Interviews with activists:

R1, R2, R3, R4, R5, R6, R7, R8.

Participant Observation in Mathare, e.g attending MSJC field events, including public forums and also data gathering on EJE and raising awareness events etc.

\footnotetext{
${ }^{1}$ Respondent (henceforth ' $R$ ') 2.

${ }^{2}$ Kenyan Citizen TV, https://www.youtube.com/watch?v=u-MhOvqySig.
} 
33 Gangsters Shot Dead Along Thika Highway, https://www.youtube.com/watch?v=95cxq3-fzBg.

${ }^{4}$ As of 2013, Mathare valley is now part of the larger Mathare Constituency. In total there are 6 wards: Hospital, Kia Maiko, Mlango Kubwa, Huruma, Mabatini and Ngei ward.

${ }^{5}$ Mungiki activity was particularly pronounced in Nairobi from approximately 1999/2000 to the mid to late 2000s, until a brutal police action especially in 2006 and into 2007 cracked down on Mungiki operations.

${ }^{6}$ To date, there are 30 recorded deaths, which typically involving excessive and unnecessary use of fire arms. For example:

${ }^{7}$ MSJC Public Forum on Land grabbing and Extra-judicial Killings, report, https://matharesocialjusticecentre.wordpress.com/(accessed December 2015).

${ }^{8} \mathrm{~A}$ common term for informal arrangements made in slums for service delivery, which are controlled by 'cartels' who control and dictate price, and so on. 